\title{
Soft Skill Improvement as a Data Update Effort in the Mekarsaluyu Village Development Program
}

\author{
Utami $^{1}$ \\ ${ }^{1}$ Study Program of Architecture, Faculty of Architecture and Design \\ Institut Teknologi Nasional Bandung, Indonesia \\ ami@itenas.com \\ Wahyu Buana Putra ${ }^{2 *}$, Dian Duhita \\ ${ }^{2,3}$ Study Program of Architecture, Faculty of Architecture and Design \\ Institut Teknologi Nasional Bandung, Indonesia \\ wbputra@itenas.ac.id, dian.duhita@itenas.ac.id
}

(Received January 31, 2021, accepted March 02, 2021)

\begin{abstract}
Natural wealth is an enormous gift. Located in northern part of Bandung, in a mountainous area, Mekarsaluyu Village has vast natural potential. The cool air, beautiful scenery, and the existence of rivers and contoured land, and the culture in the form of art and traditional music and culinary make the village has a unique local wealth. However, the local wealth available has not been managed well. The potential referred to has not yet had an optimal positive impact both on the social and economic life of its inhabitants. The background of this problem gives encouragement to empower the people of Mekarsaluyu Village by planning a tourist village development program with the theme of ecotourism. To design the program, it was necessary to collect data on the existing conditions in Mekarsaluyu Village, covering the physical aspects of natural resources and the non-physical aspects of the socio-cultural community. Getting real, accurate, and actual needs necessary to update the data and complete the lack of required data, were important for determining the ecotourism village program's planning. Therefore, the aim of this work was to carry out community service in counseling on updating data for Mekarsaluyu Village residents. The method used was in the form of training and assistance in filling out data. The writing team prepared the necessary database format tools in data variables related to the ecotourism village planning program. Then together with the residents, simulated the form filling. The results obtained from this community service are the ability of villager residents to fill in actual data independently with accuracy and validity related to physical data on the natural geographical conditions and Mekarsaluyu Village's socio-cultural community.
\end{abstract}

Keywords: natural resource; training; updating data; village development 


\section{Introduction}

Mekarsaluyu Village is one of the villages located in Cimenyan District, North Bandung Regency, located on a highland and has cool air. Its natural wealths are beautiful natural scenery, and riverbanks those are excellent and have many potential for its people. Mekarsaluyu Village also has a local culture in traditional arts and music, and culinary. Located in the mountains, this village has a contoured geographic feature and has a beautiful view of the city of Bandung. The scenery attracts the outside community as a natural tourist destination. Pedestrians, cyclists, and motorbikes on Sundays and holidays flocked the village area. This condition is a positive opportunity for the village to respond to these tourist visits. It is an excellent opportunity to improve the quality of social and economic life for its residents. However, this opportunity has not been maximized. These many positive potentials possessed by the village, if left unutilized, will gradually decrease and even fade.

Increasing economic needs making some of the residential land are converted into commercial function but are not well organized. The appearance of stalls and kiosks along the road has made the village area into a slum. If not anticipated, there will be negative impacts such as decreased environmental quality, caused by the damage to natural beauty and pollution. This problem encourages the need for village area arrangement through planning of the development program of Mekarsaluyu Village into a tourism village with the theme of ecotourism. The process towards planning the program requires data collection on the existing conditions in Mekarsaluyu Village, including the physical aspects of natural resources and the non-physical aspects of the socio-cultural community. Natural resources and natural environments that are well-preserved are essential factors of a tourist village area (Rahma \& Primasworo, 2017). However, some of the data held by these villages did not show the latest conditions, even some of the information needed for the tourism village structuring program was not available.
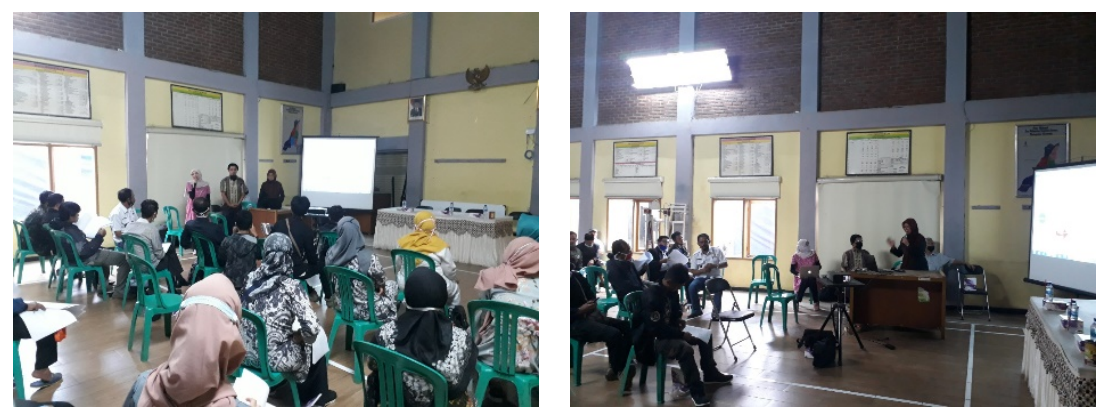

Fig. 1. Presentation and Explanation of the Importance of Updating Data for Village Development 
In order to support the program, community service was carried out in the form of counseling on updating data about Mekarsaluyu Village for the residents. The purpose of updating village development data is to produce data needed for regional development, to provide data on regional potential, infrastructure/facilities, and socio-economic conditions in each village (Badan Pusat Statistik Kabupaten Barito Utara , 2020). Analysis of village potential is useful in developing a town that follows village characteristics. The readiness and openness of the village community are needed to obtain accurate data (Susyanti, 2013). The data that needs updating was in the form of existing and current conditions in natural mapping elements, geographical conditions, land ownership boundaries, and land functions. The point was to provide information on the village's infrastructure's quality and completeness-besides data collection on demographics, socio-culture, livelihoods, and residents' skills. The wealth and uniqueness of culture, including traditional culinary delights owned by many community members, have not been revealed.

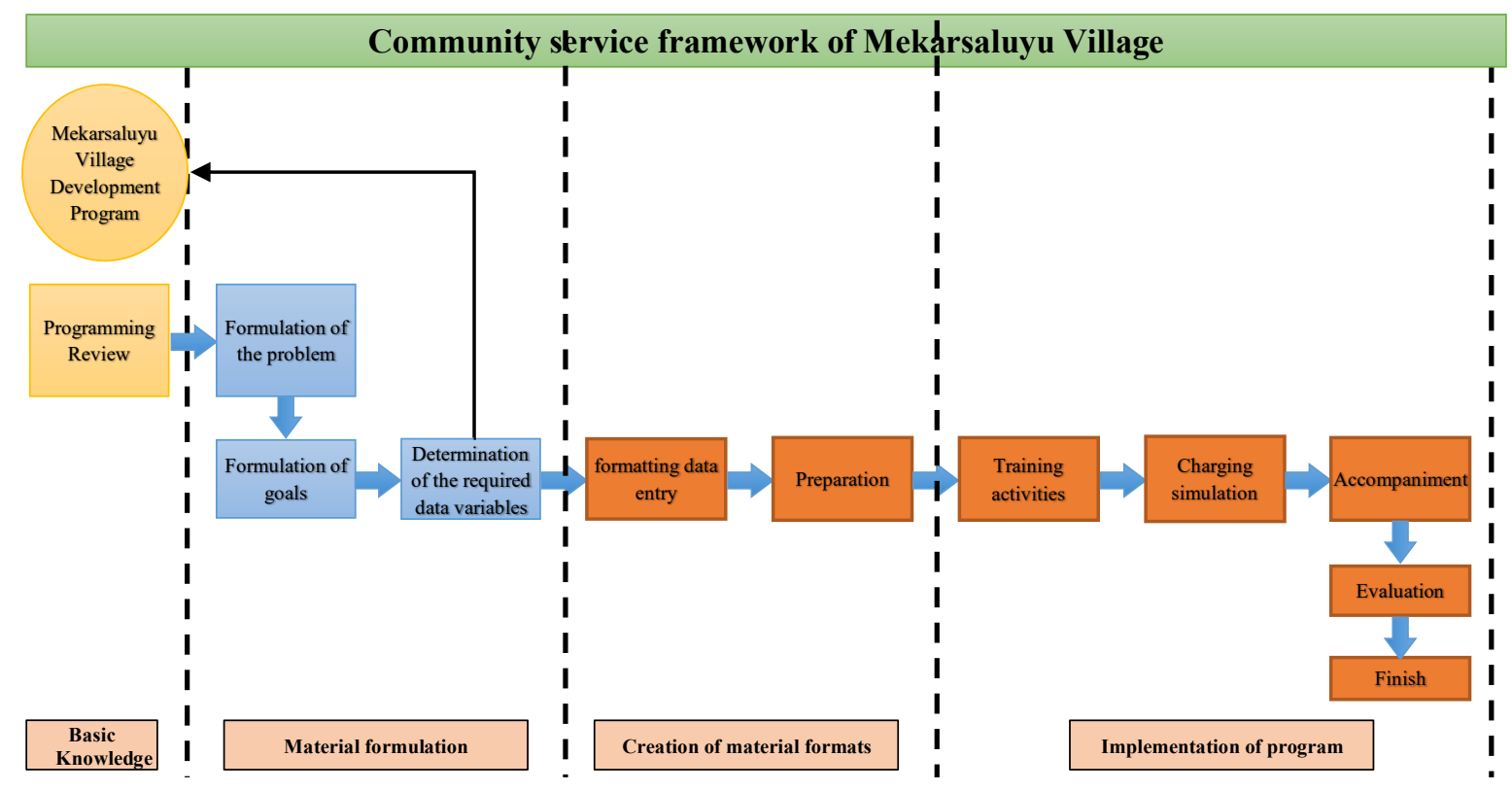

Fig. 2. Community Service Framework

Even though this was a valuable asset and was part of the tourism village's promotion, included in the structuring program, the data obtained from this update results was an essential input for the village program development direction. This community service was targeting the villager residents. The hope was that in the future, residents will have the ability to fill in data independently such that data accuracy could be obtained easier and also raising awareness about their local wealth potential. Furthermore, residents' direct participation in filling in data to support the tourism village development program will create a sense of belonging, empowering the community, both socially and economically. 


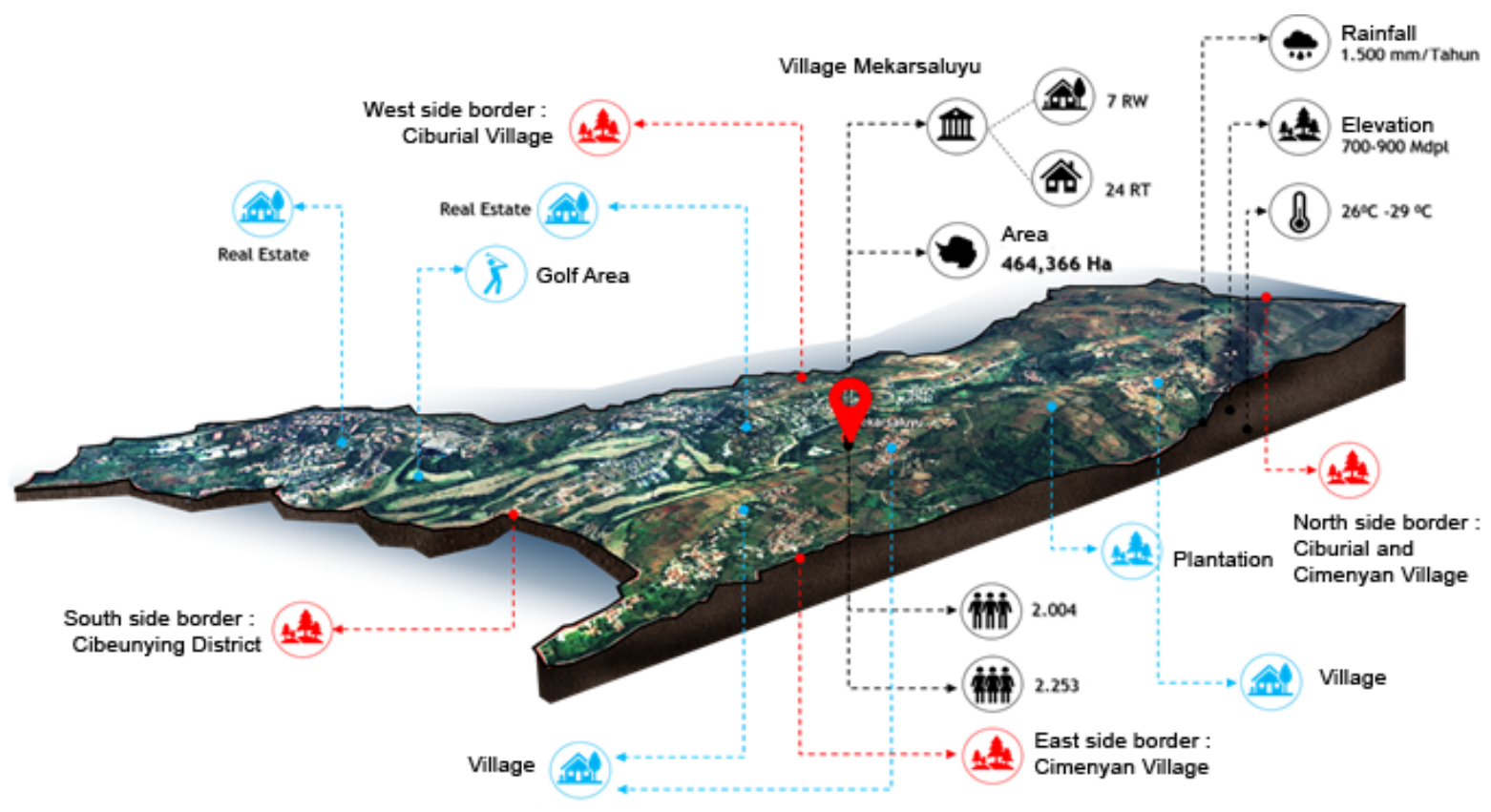

Fig. 3. Location of Mekarsaluyu Village

At the macro level, the community service activity in the form of updating Mekarsaluyu Village data is one of a series of the entire village development plan program towards a tourism village. The data updating activity is an essential first step in determining the direction of village development policymaking. The information obtained from these data will provide an overview of the potential and constraints of the village. Based on this, it received a Strength, Weakness, Opportunities, Threats (SWOT) analysis.

\section{Methods}

The method used in this community service was a community development, an approach focused on developing community empowerment by making society both the subject and the object of development. The community was directly involved in community service activities. The increase of their participation in action for their benefit. "Community development" is probably one of the most common terms used among people involved in programs in the upliftment of communities (De Wet, 2016).

This community service was carried out through training activities and simulating data entry. This activity began with the writer team's understanding of the village development program. Based on this understanding, the team formulated problems and activity objectives developed to acquire database variables. The data entry form arrangement components need to be 
concerning the village development planning program, namely as an Ecotourism Village. Then together with the residents, the team simulated the data filling. The types of data entry varied in the form of geographic mapping and measurement, land use and ownership, and the quality and quantity of the latest infrastructure conditions in Mekarsaluyu Village.
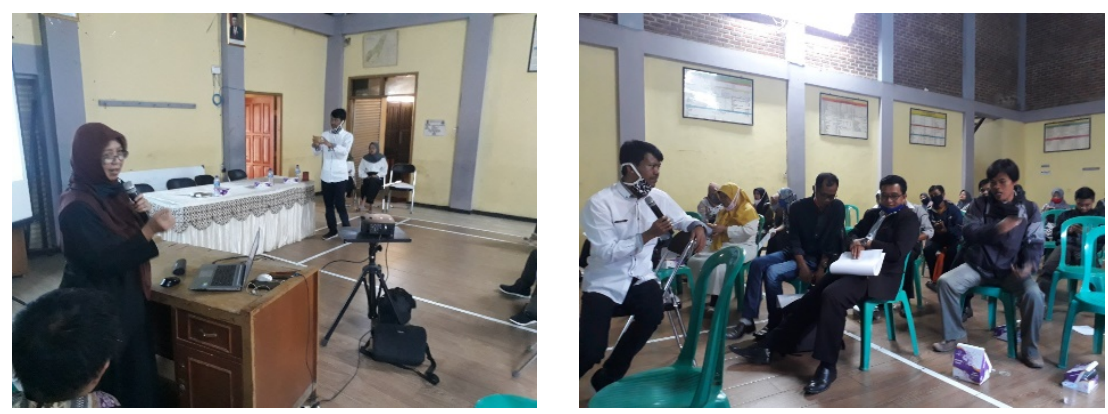

Fig. 4. Discussion, Questions and Answers with the Village Community

Non-physical data, including skills specifications, cultural arts, and culinary expertise possessed by residents, can be appointed as local cultural potentials. In the filling form simulation, each Rukun Tetangga (RT) then gradually distributed the information to its residents about how to fill in residents data. Then each resident could fill in the data by his or her own. The community was actively involved in the village development process towards a Tourism Village. Through this method, they will be more aware of the local wealth they have to increase the enthusiasm of residents in developing self-potential and Mekarsaluyu Village in general.

\section{Results and Discussions}

\section{Results}

This community service activity is part of a series of development programs for Mekarsaluyu Village as a tourist village. In order to obtain good data results in data updating activities, the residents were given an explanation of the village program. Through understanding the objectives and vision, and mission of the village program to be developed, residents can better understand the benefits of filling in the data. The explanation of the village development program raised awareness in them that the program could improve the quality of their social and economic life. The impact of opening an understanding of the benefits of the village development program was that the residents were very enthusiastic about being involved in it. The training place and atmosphere can determine the effectiveness of a training (Bangun, 2012). 


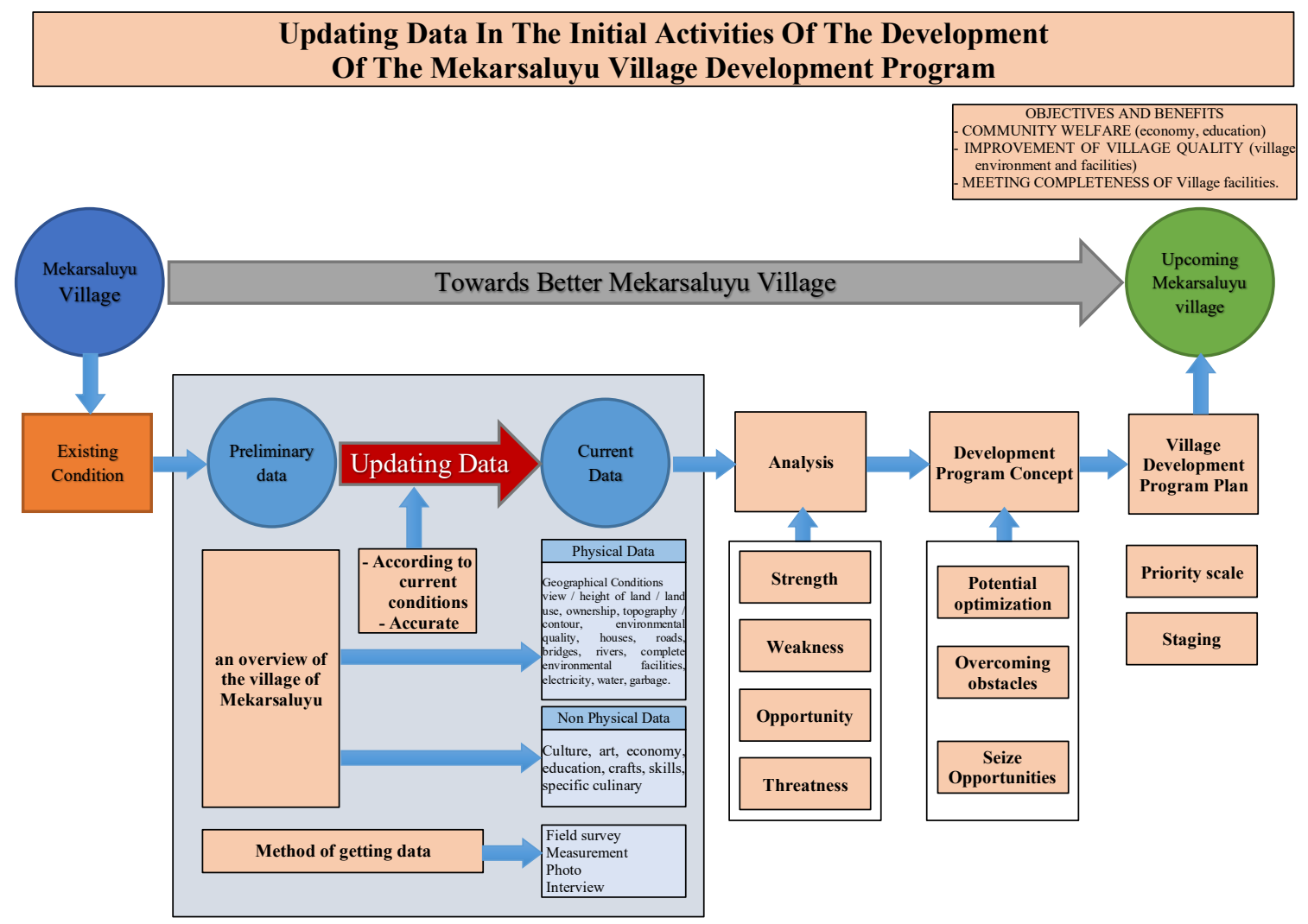

Fig. 5. Scheme of Updating Data in Early Activities of Developing the Mekarsaluyu Village Development Program

So that this data filling activity got a good response, actually, some of the data was already available in the village, but due to the very rapid recent development, the data was no longer valid, including the development data of population and social conditions of the community. This made the process of data updating to describe the current state was very important. Information and Communication Technology as part of science and technology in general are all technologies related to information retrieval, collection, processing, storage, dissemination, and presentation. The positive influence of the use of technology in the world of education in Indonesia includes, as a source of knowledge and education center, the emergence of mass media, especially electronic media such as internet networks, online media, computer laboratories in schools, are very helpful for both educators and students in doing learning process (Akbar \& Noviani, 2019). To collect type of physical data in the form of geographical conditions requires training in the form of mapping the area. Guidance and directions to fill in this type of data was given by utilizing internet. From the results of the discussion during the training, it was found that so far, the measured data for the administrative boundaries of each RT and RW in the village area had various versions that had not been disclosed so far. This creates difficulties in determining village development programs. Updating the data for 
administrative areas during the simulation of mapping the administrative boundaries has also had a positive impact on the clarity of village archives and the governance being implemented.

Things that were revealed from data filling about public facilities and village infrastructure were the acquirement of features owned and the quality that existed. Land utilized for residential, commercial, industrial, institutional, transportation, communications and general utilities were all belong to the Urban Land use categories. All other land not classified as urban, including agricultural land, farmland, cropland, rangeland and forest land belong to the Rural Landuse categories, in general (Balasubramanian, 2015). Land use change is an increase in land use from one side of use to another followed by a reduction in other types of land use at different periods of time (Wahyunto, Priyono, \& Sunaryo, 2001). Meanwhile, land use and ownership status in the village have several complex problems. Some lands do not yet have clear ownership status, while the land is used by other parties. Of course, this affects the village development planning program. Due to the development of the physical planning of the tourism village, it was planned that it will be equipped with natural tourism, gardens, and livestock that involve residents. It was hoped that through filling in this data, the latest information will be generated that could clarify the position and limits of ownership of each land parcel. Some of the recorded lands have changed their function and ownership. Even the private sector has taken over the management of agricultural land with a large enough area. From the data entry, it was revealed that the local wealth owned by the village of Mekarsaluyu was in the form of vegetable gardens, oranges, and several facilities for goat and cow farming.

Meanwhile, the potential natural wealth of this village is the Cilimus River. This village development program would use the potential of the river as a processing zone for tourist areas. This is a synergy with the government program "Citarum Harum" as stated in PERPRES No. 15 year 2018. To find out the use of land along the riverbanks, the variables were written in the form. The results obtained from the training and the filling simulation indicated that the residents used it as a spring area found on river cliffs. However, it is unfortunate that at some point it was used as a garbage disposal area. 

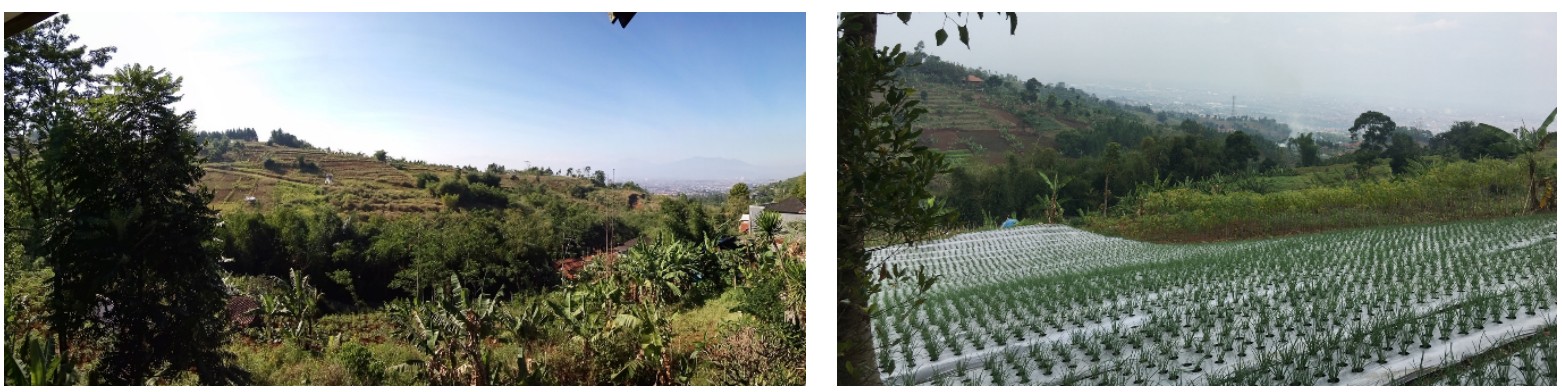

Fig. 6. (Left) Mekarsaluyu Village on a Hill; (Right) Potential Agricultural Land in the Village of Mekarsaluyu

\section{Discussions}

Filling in non-physical data, in the form of socio-cultural aspects, especially exploring the expertise and skills of citizens arts and culture. As part of the development program as a tourism village, this data is important for program direction. Through the development of rural tourism or tourism village, then a tourism destination will have the diversity of tourist products that would open up opportunities return visit for tourists who travelled to the area (Irfan \& Suryani, 2017). To find out more accurate data, this training program was also attended by PKK women in Mekarsaluyu Village.
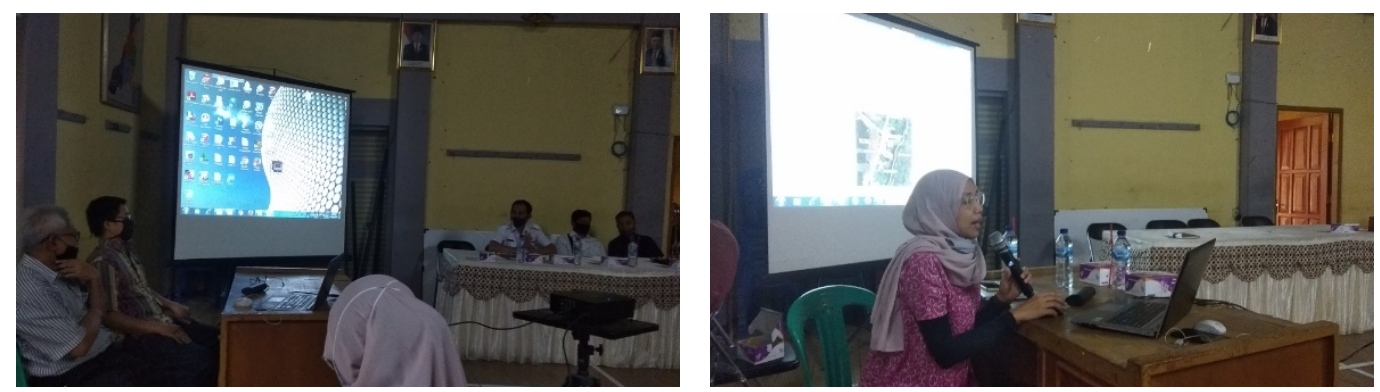

Fig. 7. (left) Opening of the Discussion by the Village Head; (right) The explanation was Delivered by Ms. Dian Duhita

Based on the discussions held together, it turned out that Mekarsaluyu Village has a lot of hidden potential. Culinary riches that make creative use of local ingredients were found. Meanwhile, the skill of processing bamboo materials which are abundant along the banks of the Cilimus River was an aspect that has not been explored optimally. This could become information material for holding skills training programs for the youth. Meanwhile, based on the results of the discussion on filling in the data, it was obtained information on the wealth of music and dance, which were also stored in this village. Some silat and dance heritage were owned by residents, but they have not been used optimally. 
Table 1. Mekarsaluyu Village Data Update Form, Cimenyan District, Bandung Regency

Name

Rukun Tetangga (RT)

Rukun Warga (RW)

Date/Month/Years

\begin{tabular}{|c|c|c|c|c|}
\hline No & DESCRIPTION & MAP & PICTURE & NOTE \\
\hline (1) & (2) & (3) & (4) & (5) \\
\hline & $\begin{array}{l}\text { Display and describe data that must be informed } \\
\text { clearly and correctly }\end{array}$ & $\begin{array}{l}\text { Display } \\
\text { Location, } \\
\text { Position/ } \\
\text { Path/ } \\
\text { Network via } \\
\text { Image - } \\
\text { Map. }\end{array}$ & $\begin{array}{l}\text { Displaying the } \\
\text { atmosphere, the } \\
\text { real condition of } \\
\text { the data } \\
\text { information in the } \\
\text { column (2) }\end{array}$ & $\begin{array}{l}\text { Describe in detail the } \\
\text { actual } \\
\text { condition/condition of } \\
\text { each data information in } \\
\text { the column (2) }\end{array}$ \\
\hline I. & GEOGRAPHIC CONDITIONS & & & \\
\hline 1. & Area $\ldots . . \mathrm{km}^{2}$ & Complete & & \\
\hline 2. & Boundary - Territory: (Adm \& function area) & maps & & \\
\hline 3. & Altitude ranges ....m ASL & otos & & \\
\hline
\end{tabular}

\begin{tabular}{|c|c|c|}
\hline II. & LAND USE & \\
\hline & Function \& Area & \\
\hline 1. & $\begin{array}{l}\text { Settlement: .... m² } \\
\text { Land Status: (private, rent, public, waqf, etc.) }\end{array}$ & \\
\hline 2. & $\begin{array}{l}\text { Agriculture/Plantation: ..... } \mathrm{m}^{2} \\
\text { Land Status: .... }\end{array}$ & \\
\hline 3. & $\begin{array}{l}\text { Livestock: .... unit } \\
\text { Land Status: .... }\end{array}$ & \\
\hline 4. & $\begin{array}{l}\text { Trade/Commercial: ..... unit } \\
\text { Land Status: .... }\end{array}$ & \\
\hline 5. & $\begin{array}{l}\text { T. Worship: unit }\left( \pm \ldots \mathrm{m}^{2}\right) \\
\text { Land Status: }\end{array}$ & Complete \\
\hline 6. & $\begin{array}{l}\text { Posyandu/Clinic/Puskesmas: .... unit }\left( \pm \ldots . \mathrm{m}^{2}\right) \\
\text { Land Status: .... }\end{array}$ & \\
\hline 7. & $\begin{array}{l}\text { Education: .... unit, } \ldots . . \mathrm{m}^{2} \\
\text { Land Status: .... }\end{array}$ & \\
\hline
\end{tabular}

8. Park/Open space .... $\mathrm{m}^{2}$

Land Status: ....

9. Cemetery: 1 piece/area .... $\mathrm{m}^{2}$

Land Status: ....

10. $\quad$ Etc. (can be filled in according to field conditions)

III. LAND CHARACTERISTICS

1. Topographic Conditions/Land Slope:

(Flat/Slope/Ridge)

If contoured/tilted, slope of approx: $0^{\circ}-\ldots{ }^{\circ}$.

Highest elevation on the side: .... (North, West,

South, East of Land)

Lowest exploration on the side: .... (North, West, South, East Land)

Complete

with a map

\section{Condition:}

Land slope: (function

in each slope area of land-Hill, Slope,

Valley)

Soil Quality:

(fertile, barren, rocky,

etc.)

Groundwater:

(quality \& quantity, level of accessibility of ground water)

Vegetation/Plants:

(quantity, quality, level of benefit, etc.)

\footnotetext{
2. Soil/Geology: .... (Laterite/Rocks/Sand/etc.)

3. Groundwater:

Depth around .... m, (Deep well, not affected by rainy or dry season conditions)

The depth around .... m, (Shallow well, influenced by rainy or dry season conditions)
} 
4. Vegetation/Plants:

Types of plants in the riverbank area

Types of plants on the side of the highway

Types of plants in the vacant land area

Types of plants in the residential area

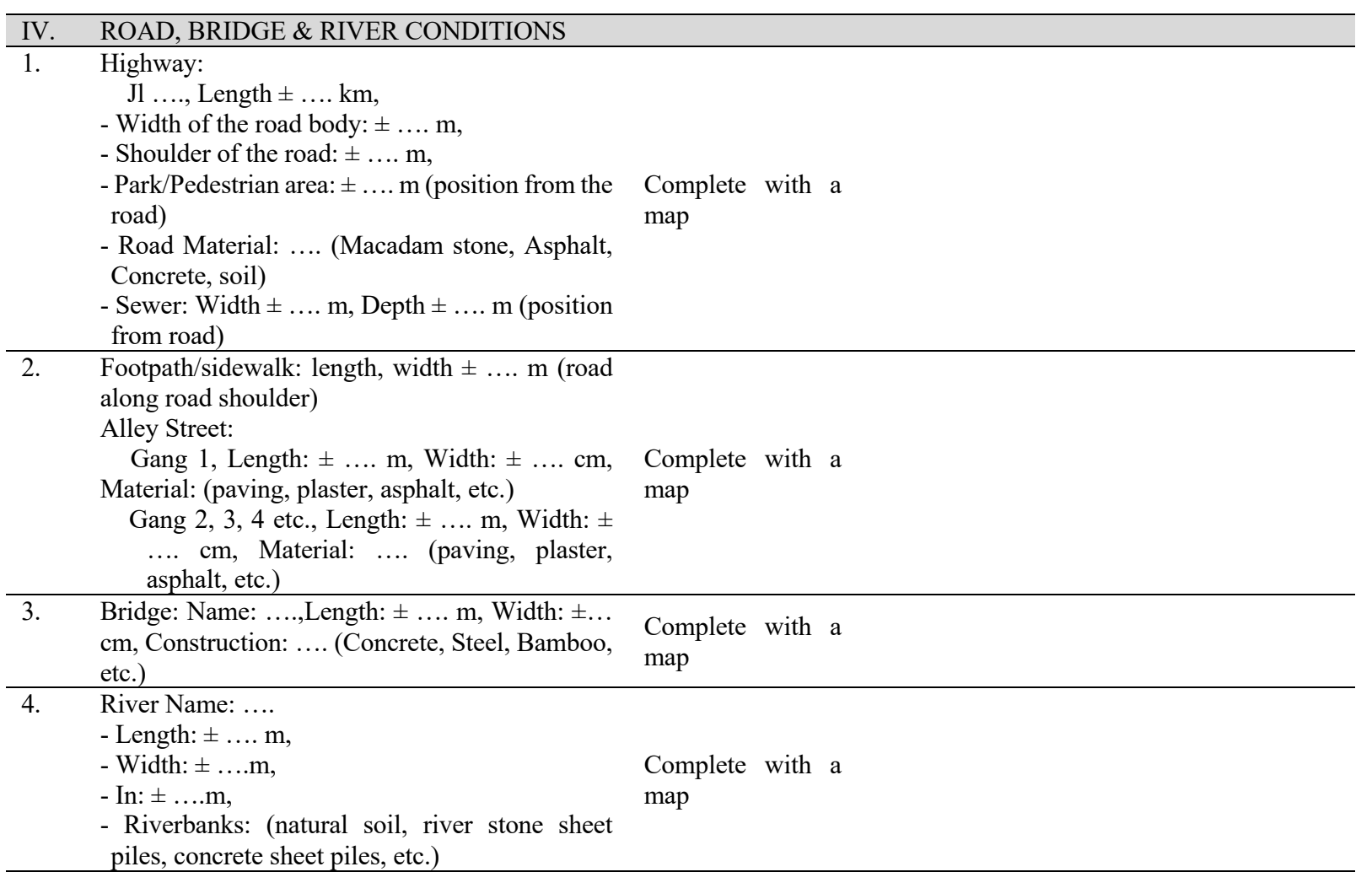

\begin{tabular}{|c|c|c|c|}
\hline V. & SETTLEMENT FORM PATTERN & & \\
\hline 1. & Group: .... (Yes, No) & & \multirow{5}{*}{$\begin{array}{l}\text { Condition: } \\
\text { Location of settlement } \\
\text { on the east side of Jl. } \\
\text { Ciharalang } \\
\text { The position of } \\
\text { landslide-prone } \\
\text { residential groups is in } \\
\text { the land area: } \\
\text { Residential position on } \\
\text { the river bank } \\
\text { facing/backwards to } \\
\text { the river) }\end{array}$} \\
\hline 2. & Linear following Path: .... (Yes, No) & & \\
\hline \multirow[t]{3}{*}{3.} & Scattered/Clustered: .... (Yes, No) & & \\
\hline & & $\begin{array}{l}\text { Complete with a } \\
\text { map }\end{array}$ & \\
\hline & & & \\
\hline
\end{tabular}

\begin{tabular}{llll}
\hline VI & BUILDING CONDITIONS (Construction) & & \\
\hline & Permanent Building: .... (unit) & $\begin{array}{l}\text { Image of the map } \\
\text { of the position of } \\
\text { building classes in } \\
\text { the administrative } \\
\text { Semi Permanent Building:.... (unit) }\end{array}$ & $\begin{array}{c}\text { Condition: } \\
\text { area of RT }\end{array}$ \\
\cline { 2 - 4 } & Temporary Building: .... (unit) & quality \\
& & & \\
&
\end{tabular}

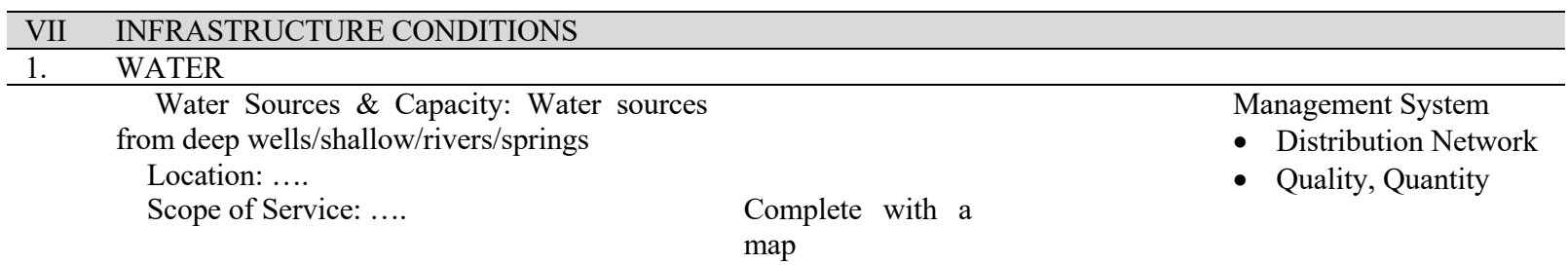




\begin{tabular}{ll}
\hline 2. & GREY WATER/SANITATION \\
\hline & Private latrine + Septic tank: .... unit \\
& Private Toilet + Cubluk: ... unit \\
& Private Latrine without Septiktank/Cubluk: \\
& fruit \\
Communal MCK: .... (Yes, Nothing). \\
- Location: \\
- Manager: \\
- Service Coverage: \\
- Power Source: \\
- Building conditions:
\end{tabular}

$\begin{array}{lrlr}\text { Image } & \text { of } & \text { Photo } & \text { of } \\ \text { Sanitation } & \text { Map, } & \text { Sanitary } & \text { Final } \\ \text { Position } & \text { of } & \text { Disposal } & \\ \text { Communal } & \text { MCK } & \text { Conditions } \\ \text { in } & \text { RT } & \\ \text { administrative } & & \\ \text { area } & & \end{array}$

ondition:

Considerations for

Determination of

Sanitation Systems:

....

Conditions that occur

from the use of the

Sanitation System

used: ....

Conditions of

Communal MCK

(Management,

Service Coverage,

Water Sources,

Electricity, Building

Conditions):

\begin{tabular}{ll}
\hline 3. & RAIN WATER DRAINAGE \\
\hline & Drainage system: .... (open sewers, closed \\
gutters, infiltration, biopores). \\
Management: .... (allowed to flow gravity into \\
the area underneath the land). \\
Final distribution of rainwater: .... (discharged \\
into ditches/rivers/ponds/infiltration/biopores) \\
\\
WASTE \& SOLID WASTE \\
Waste Management Method: .... \\
(Disposed out of the environment, dumped in \\
the environment, Burned). \\
Public polling station on the roadside: .... \\
(Yes, Nothing) \\
Domestic TPS in the Environment: .... \\
(Yes, None) \\
Bank 3R: .... (Yes, Nothing) \\
TPS location: .... \\
TPS capacity: .... ${ }^{3}$ \\
Mode/means of transportation for garbage:....
\end{tabular}

Draw Drainage

Path Map, River

Position, Pond,

etc. which is in the

administrative

area of RT

\section{Sewerage}

Drainage

Condition

Photo

Photo of River

Condition
Condition:

River when it rains:

Impact that occurs

Drainage network during rain: quantity and quality) Impact on

Settlements

Environment

\begin{tabular}{|c|c|}
\hline $\begin{array}{l}\text { Image of TPS } \\
\text { Position Map, 3R } \\
\text { Bank, Burnt } \\
\text { Waste, Disposal in } \\
\text { the environment in } \\
\text { the RT } \\
\text { administration } \\
\text { area }\end{array}$ & $\begin{array}{l}\text { - Photo of } \\
\text { General } \\
\text { Area } \\
\text { Garbage } \\
\text { Condition } \\
\text { - Photo of Sol } \\
\text { Waste in } \\
\text { Residential } \\
\text { Area (dome } \\
\text { waste) } \\
\text { - Photo of } \\
\text { Solid Waste } \\
\text { Waste } \\
\text { Condition }\end{array}$ \\
\hline
\end{tabular}

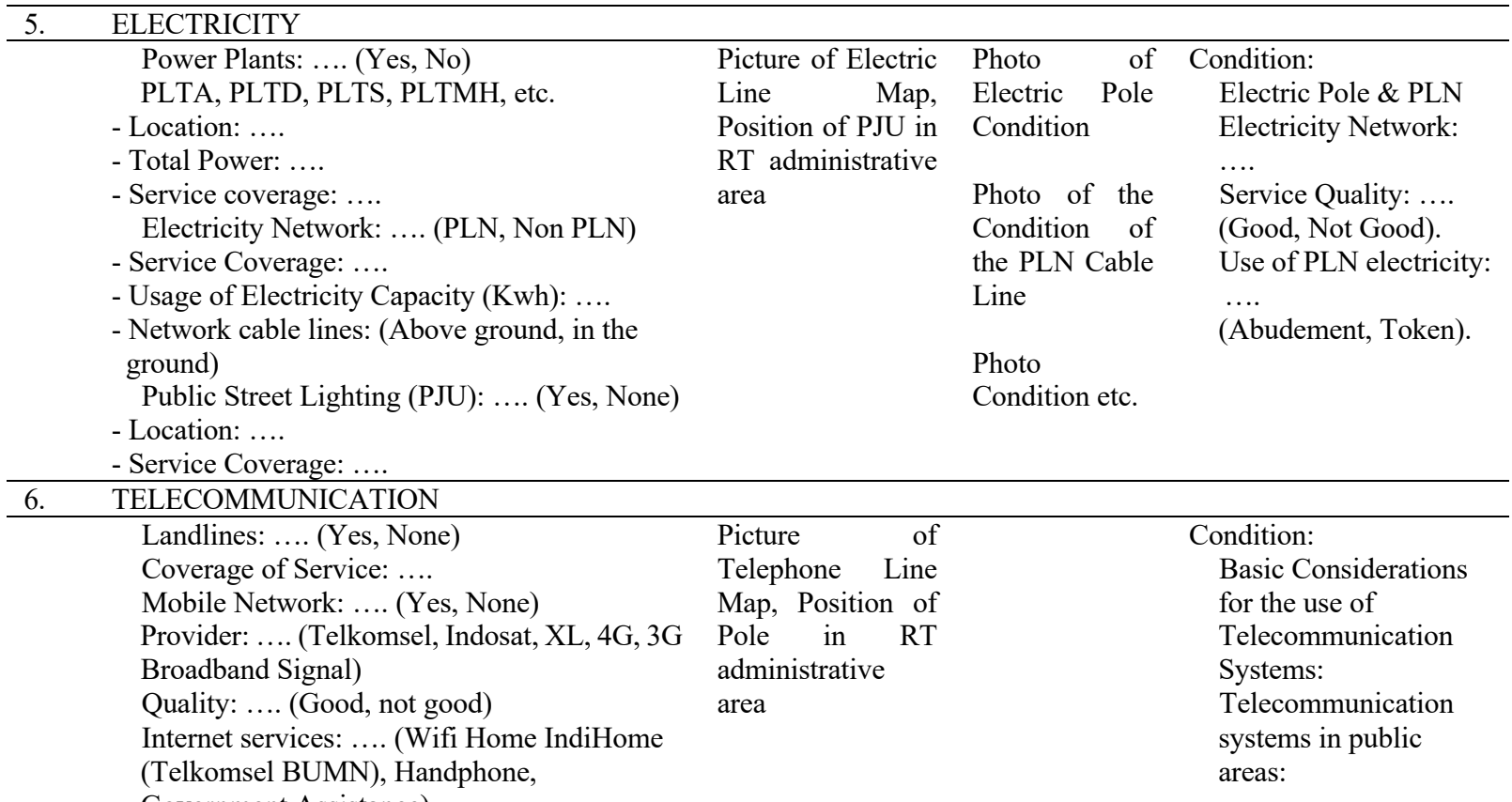

\section{Condition:}

Basic considerations for determining the management system: .

Impact of the Waste Management System: .... ste)

Waste 


\begin{tabular}{|c|c|c|}
\hline \multicolumn{3}{|c|}{ NON PHYSICAL DATA } \\
\hline No. & FAMILY CARD & DESCRIPTION: MORE SKILLS/SPECIALIZATION \\
\hline$(1)$ & (2) & (3) \\
\hline & $\begin{array}{l}\text { Enter the existing Family Card Form } \\
\text { (update) }\end{array}$ & $\begin{array}{l}\text { Describe the Special Skills/Specialties/Certain Conditions or } \\
\text { Limitations (Handycap) in Column (2) }\end{array}$ \\
\hline & EXISTING FAMILY CARD FORM & $\begin{array}{l}\text { 1. Cultural Arts: } \\
\text { 2. Arts Crafts: } \\
\text { 3. The Art of Food / Culinary Processing: } \\
\text { 4. Technological Skills (Mechanical, IT/Computer, Electronic, } \\
\text { Electrical, Agriculture, Animal Husbandry, etc.): } \\
\text { 5. Limitations: } \\
\text { 6. Etc. }\end{array}$ \\
\hline
\end{tabular}

\section{Conclusion}

The training program for filling in data in order to update the latest information on geographical conditions, natural resources, and culture of Mekarsaluyu Village was quite successful and received good response from the community. Through filling in the prepared filling forms and using a simple computer program, this training went well. The data filling training as well as the data filling simulation including inserting images into tables using basic computer programs, such as Microsoft Word and Excel, were quite successfully understood by the participants. Especially through the presence of participants from the younger generation consisting of representatives from each community group. Furthermore, the results of this training were relayed to the residents in each area, so that gradually this ability spreads to the villagers. Thus, residents as parties who know more about the specifications of their own environmental conditions could independently collect data. The positive side obtained from this data entry training activity was the participation of village officials, citizen representatives, and the young generation of the village together, where every element of society synergized with each other to provide information about the potential of the village.

Furthermore, it is hoped that this data entry training program will produce up-to-date and accurate information. The results of the data input obtained will be needed as a reference for determining the village development program towards a tourist village. This is very important considering that village development certainly needs to be supported by the condition of the village it has.

\section{Acknowledgements}

Thank you to the Head of Mekarsaluyu Village, who has given us the opportunity to help Mekarsaluyu Village in the Tourism Village development program and to be part of 
community service activities which are the tridarma duties of a lecturer. Not to forget, we would like to thank the Institute for Research and Community Service (LP2M) Bandung National Institute of Technology for their assistance and cooperation.

\section{References}

Akbar, A., \& Noviani, N. (2019). Tantangan dan Solusi dalam Perkembangan Teknologi Pendidikan di Indonesia. Seminar Nasional Pendidikan Program Pascasarjana Universitas PGRI Palembang, (pp. 18-25).

Badan Pusat Statistik Kabupaten Barito Utara . (2020). Retrieved from Pemutakhiran Data Desa:

https://barutkab.bps.go.id/news/2020/06/09/23/pemutakhiran-dataperkembangan-desa--updating-podes--2020.html

Balasubramanian, A. (2015). Categories of Landuse. Retrieved from Researchgate: https://www.researchgate.net/publication/309785988_CATEGORIES_OF_LANDUS $\mathrm{E}$

Bangun, W. (2012). Manajemen Sumber Daya Manusia. Jakarta: Erlangga.

De Wet, S. (2016). Community Development and Community Participation: A Conceptual Revisit. Retrieved from Researchgate:

https://www.researchgate.net/publication/307560360_COMMUNITY_DEVELOPME NT_AND_COMMUNITY_PARTICIPATION_A_CONCEPTUAL_REVISIT

Irfan, M., \& Suryani, A. (2017). Local Wisdom Based Tourist Village Organization in Lombok Tourist Area. International Journal of English Literature and Social Sciences (IJELS), 2(5), 073-082.

Rahma, P. D., \& Primasworo, R. A. (2017). Identifikasi Potensi \& Masalah Desa Sidomulyo Sebagai Upaya Pengembangan Desa Wisata Di Kota Batu. Jurnal Reka Buana, 2(1), 089-097.

Susyanti, D. W. (2013). Potensi Desa Melalui Pariwisata Pedesaan. Jurnal Ekonomi dan Bisnis, 12(1), 33-36.

Wahyunto, M. A., Priyono, A., \& Sunaryo. (2001). Studi Perubahan Lahan di Sub DAS Citarik, Jawa Barat dan DAS Kaligarang Jawa Tengah. Seminar Nasional Multifungsi Lahan Sawah, (pp. 39-48). 